\section{International Scientific Journal Theoretical \& Applied Science}

p-ISSN: 2308-4944 (print) $\quad$ e-ISSN: 2409-0085 (online)

Year: $2016 \quad$ Issue: 6 Volume: 38

Published: $30.06 .2016 \quad \underline{\text { http://T-Science.org }}$

SECTION 20. Medicine.
Sarviniso Islamovna Ibragimova Master's Student in Medical Sciences International Kazakh-Turkish University by name Yassavi, Kazakhstan sarvinsa@mail.ru

Kumisai Sabetovna Babayeva Candidate of medical science, a.e. association professor Head of the Department of Emergency Medical Care International Kazakh-Turkish University by name Yassavi, Kazakhstan atu1972@mail.ru

Assel Dauletbaevna Sadykova $\mathrm{PhD}$ Student in Medicine Sciences International Kazakh-Turkish University by name

Yassavi, Kazakhstan asikosha@inbox.ru

Gulshad Gafurxanovna Sharabitdinova Master`s Student in Medical Sciences International Kazakh-Turkish University by name

Yassavi, Kazakhstan sharabitdinova80@inbox.ru

Zhanar Sailaubekovna Shalkharova DM, Vice-president GI "Educational and Healthcare Holding" zhanar.shalkharova@gmail.com

Zhanat Nagmetovna Shalkharova DM, Professor International Kazakh-Turkish University by name Yassavi, Kazakhstan janatsh@mail.ru

\title{
ELECTROCARDIOGRAPHIC ABNORMALITIES IN SUBJECTS WITH OVERWEIGHT, OBESITY AND ABDOMINAL OBESITY
}

Abstract: This article presented the prevalence of ECG abnormalities in subjects with overweight, obesity and abdominal obesity.

Key words: electrocardiogram, major and minor abnormalities, obesity

Language: English

Citation: Ibragimova SI, Babayeva KS, Sadykova AD, Sharabitdinova GG, Shalkharova ZS, Shalkharova ZN (2016) ELECTROCARDIOGRAPHIC ABNORMALITIES IN SUBJECTS WITH OVERWEIGHT, OBESITY AND ABDOMINAL OBESITY. ISJ Theoretical \& Applied Science, 06 (38): 31-35.

Soi: http://s-o-i.org/1.1/TAS-06-38-7 Doi: crossef http://dx.doi.org/10.15863/TAS.2016.06.38.7

BACKGROUND: Cardiovascular diseases (CVD) are the current problem of the world due to the high morbidity and mortality rate among the employable population. Despite progress in the prevention and treatment of CVD, they are still lead in the structure of morbidity and significantly affect such basic health indicators as morbidity, disability, mortality. As noted by many researchers, the level of cardiovascular morbidity and mortality in developed countries is reduced from year to year, whereas this figure tends to increase in developing countries [1,2].

Considering the evolution of the CVD, we can establish that mortality from CVD atherosclerotic origin grew rapidly in industrialized countries since World War II. This led to the conduct of epidemiological studies in Europe, which began in 1950, in particular in the USA Framingham study. Three main cardiovascular risk factors - high cholesterol, hypertension and smoking regularly 
appeared in epidemiological studies until 1975. The last twenty years have confirmed the importance of these three risk factors, which are long-term predictors of adverse outcome of CVD. Several polymorphisms of genes have been shown to be associated with increased risk of developing CVD. Despite this, in the 90 years studies devoted to secondary prevention were priority than primary prevention [3-7]. As reported in the MONICA study, due to adequate secondary prevention observed reduction in mortality from myocardial infarction, while the morbidity remains stable. Similar conclusions were reached in the study REACH, which shows the lack of effectiveness of secondary prevention. DREAM study found that none ramipril and rosiglitazone does not reduce the incidence of cardiovascular events [8-10]. All this is of great interest and requires further study cardiovascular risk factors and the development of primary prevention measures.

Together with the study of behavioral and biological risk factors, is currently in the scientific world actively discussed the role of electrocardiographic (ECG) abnormalities, for an objective evaluation of the CVD. It was found that ECG abnormalities are significant prognostic marker of CVD independently of traditional risk factors [11].

Among the risk factors of CVD, obesity is the most common. Risk due to obesity contributes to the development of coronary and cerebral disorders in obese patients. In obesity observed damage of vessels, due to the fact that obesity predisposes to the development of dyslipidemia, diabetes, hypertension and sudden cardiac death. Besides these mechanisms, in obesity cardiomyocytes changes, characterized by degenerative phenomena [12]. ECG pathology more common in obese patients, which are manifested in the form of lower voltage, left ventricular hypertrophy, extension of left atrial [13]. There is evidence that visceral fat causes the appearance of pathologic ECG due to sympathetic activation, and was described cases of arrhythmia in patients with obesity [14]. In addition, weight loss was accompanied by the elimination of ECG abnormalities [15], which is similar to the results of research Colombia and Italy $[16,17]$.

Along with the association between ECG abnormalities and overweight, obesity, in the study of Korean scientists revealed the relations with the abdominal obesity.
AIM: Aim of present study is to investigate the prevalence of ECG changes depending on body mass index (BMI) and value of waist circumference in residents of Turkestan.

DESIGN, MATERIALS AND METHODS: Design of the study is based on a cross-sectional population-based study conducted in Turkestan region. Out of whole sample (1143 respondents), ECG changes have been studied in 14\% (158). Out of all 158 patients, number of men was 48 , women 110 , respectively. The average rate of age of the studied men and women were $50.1 \pm 13.7$ and $52.1 \pm$ 13.7 consequently. Height and weight were measured while subjects were wearing light clothing without shoes. Waist circumference was measured midway between the costal margin and the iliac crest at the end of a normal expiration. BMI was calculated as weight in kilograms divided by the square of height in meters.

Standard 12-lead ECGs were recorded with each subject in the supine position using strictly standardized procedures. ECGs were coded by a cardiology specialist using the Minnesota system [18]. ECG abnormalities were divided into minor and major abnormalities based on Minnesota criteria.

Major ECG abnormalities included:

3-1,4-1-Left ventricular hypertrophy (LVH)

4-1, 4-2-Major ST-T abnormalities

7-1-Complete left bundle branch block (LBBB)

8-3-Atrial fibrillation (AF)

Minor ECG abnormalities included:

5-3-Minor ST-T abnormalities (RBBB)

7-3-Incomplete right bundle branch block

7-6-Left posterior fascicular block (LPFB)

7-7-Left anterior fascicular block (LAFB)

8-1-1, 8-1-2, 8-1-3 Extrasystoles

8-7-Sinus tachycardia

9-7-Early repolarization

Sinus arrhythmia

The data was obtained using statistical package of program - Biostat. A chisquare $\left(\chi^{2}\right)$ test was used to compare prevalence rates of ECG abnormalities between groups with and without the obesity and abdominal obesity.

RESULTS: Determinants of ECG changes of 158 patients showed in Fig. 1. In $36.7 \%$ of patients pathological ECG changes were not registered. Out of major abnormalities the most often pathology was $\mathrm{LVH}$, of minor abnormalities was incomplete bundle branch blocks. 


\begin{tabular}{l|lrl|l|ll} 
& ISRA (India) & $=\mathbf{1 . 3 4 4}$ & SIS (USA) & $=\mathbf{0 . 9 1 2}$ & ICV (Poland) & $=\mathbf{6 . 6 3 0}$ \\
Impact Factor: & ISI (Dubai, UAE) $=\mathbf{0 . 8 2 9}$ & PUHЦ (Russia) & $=\mathbf{0 . 2 3 4}$ & PIF (India) & $=\mathbf{1 . 9 4 0}$ \\
& GIF (Australia) & $\mathbf{0 . 5 6 4}$ & ESJI (KZ) & $=\mathbf{1 . 0 4 2}$ & IBI (India) & $=\mathbf{4 . 2 6 0}$ \\
& JIF & $\mathbf{1 . 5 0 0}$ & SJIF (Morocco) & $\mathbf{2 . 0 3 1}$ & & \\
\hline
\end{tabular}

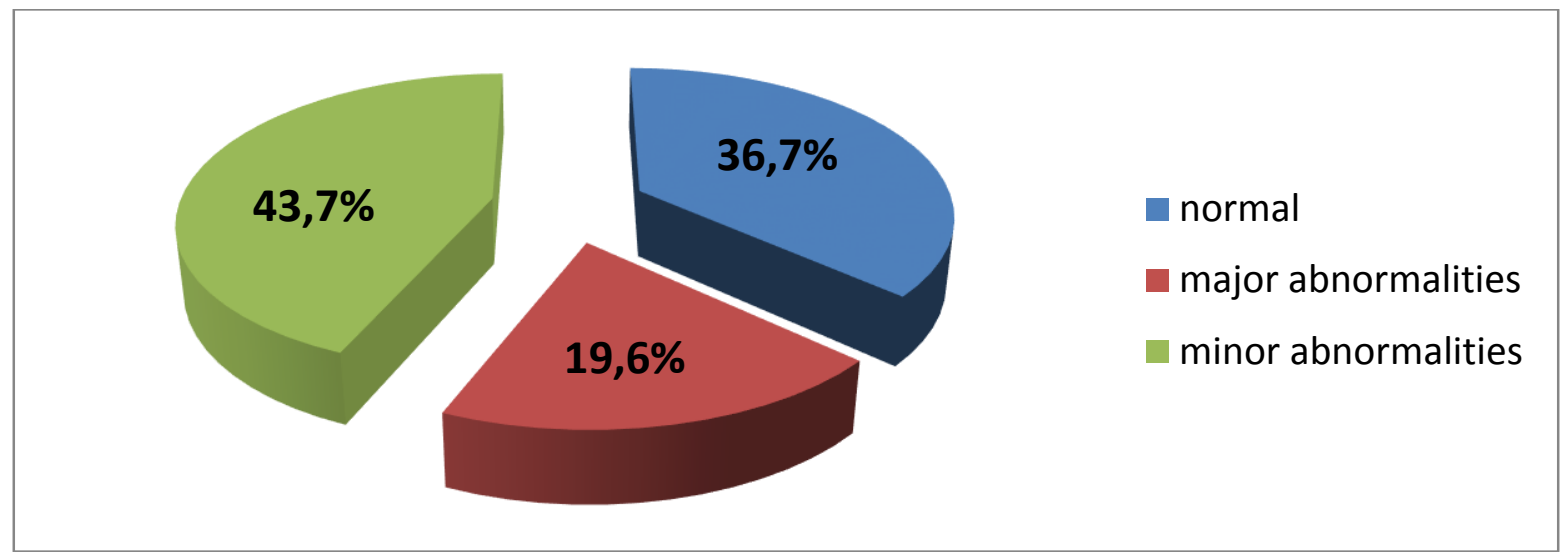

Figure 1 - Structure of ECG changes according to the Minnesota coding system.

Table 1

Prevalence of major and minor ECG abnormalities by Minnesota criteria in subjects with or without overweight and obesity.

\begin{tabular}{|c|c|c|c|c|c|}
\hline \multirow{2}{*}{$\begin{array}{c}\text { Minnesota coding } \\
\text { system }\end{array}$} & \multirow{2}{*}{ ECG abnormalities } & \multicolumn{2}{|c|}{ BMI $<25$} & \multicolumn{2}{|c|}{ BMI > 25 } \\
\hline & & $\mathbf{n}$ & $\%$ & $\mathbf{n}$ & $\%$ \\
\hline \multirow{5}{*}{ Major abnormalities } & LVH & 10 & 14,1 & 16 & 18,5 \\
\hline & Major ST-T abnormalities & & & & \\
\hline & & 1 & 1,4 & 1 & 1,1 \\
\hline & Complete LBBB & 1 & 1,4 & 1 & 1,1 \\
\hline & $\mathrm{AF}$ & - & - & 1 & 1,1 \\
\hline \multirow{9}{*}{ Minor abnormalities } & Minor ST-T abnormalities & & & & \\
\hline & & - & - & 2 & 2,3 \\
\hline & Incomplete RBBB & 5 & 7 & 9 & 10,4 \\
\hline & LPFB & - & - & 1 & 1,1 \\
\hline & LAFB & 21 & 29,6 & 20 & 22,9 \\
\hline & Extrasystoles & 1 & 1,4 & 2 & 2,3 \\
\hline & Early repolarization & 1 & 1,4 & 4 & 4,7 \\
\hline & Sinus tachycardia & 1 & 1,4 & 1 & 1,1 \\
\hline & Sinus arrhythmia & - & - & 1 & 1,1 \\
\hline \multicolumn{2}{|r|}{ Normal } & 30 & 42,2 & 28 & 32,3 \\
\hline \multicolumn{2}{|c|}{ Overall } & 71 & 100 & 87 & 100 \\
\hline
\end{tabular}

Table 2 shows that the frequency of ECG abnormalities was not different statistically among individuals with and without overweight and obesity, living in Turkestan region.

Table 2

Prevalence of major and minor ECG abnormalities by Minnesota criteria in subjects with or without abdominal obesity.

\begin{tabular}{|c|l|c|c|c|c|}
\hline \multirow{2}{*}{$\begin{array}{c}\text { Minnesota coding } \\
\text { system }\end{array}$} & \multirow{2}{*}{ ECG abnormalities } & \multicolumn{2}{|c|}{$\begin{array}{c}\text { WS }<\text { 94 men } \\
\text { WS < 80 women }\end{array}$} & \multicolumn{2}{c|}{ WS $>$ 80 women } \\
\cline { 3 - 6 } & & $\mathbf{n}$ & $\mathbf{\%}$ & $\mathbf{n}$ & \% \\
\hline & LVH & 9 & 13,2 & 17 & 18,9 \\
\hline
\end{tabular}




\begin{tabular}{|c|c|c|c|c|c|c|}
\hline Impact Factor: & $\begin{array}{l}\text { ISRA (India) } \\
\text { ISI (Dubai, UAE } \\
\text { GIF (Australia) } \\
\text { JIF }\end{array}$ & $\begin{array}{l}=1.344 \\
=0.829 \\
=0.564 \\
=1.500\end{array}$ & $\begin{array}{l}\text { SIS (USA) } \\
\text { PИНЦ (Russia) } \\
\text { ESJI (KZ) } \\
\text { SJIF (Morocco) }\end{array}$ & $\begin{array}{l}=0.912 \\
=0.234 \\
=1.042 \\
=2.031\end{array}$ & $\begin{array}{l}\text { ICV (Poland) } \\
\text { PIF (India) } \\
\text { IBI (India) }\end{array}$ & $\begin{array}{l}=6.630 \\
=1.940 \\
=4.260\end{array}$ \\
\hline
\end{tabular}

\begin{tabular}{|c|c|c|c|c|c|}
\hline \multirow[t]{4}{*}{ Major abnormalities } & Major ST-T abnormalities & & & & \\
\hline & & 1 & 1,5 & 1 & 1,1 \\
\hline & Complete LBBB & 1 & 1,5 & 1 & 1,1 \\
\hline & $\mathrm{AF}$ & - & - & 1 & 1,1 \\
\hline \multirow{9}{*}{ Minor abnormalities } & Minor ST-T abnormalities & & & & \\
\hline & & - & - & 2 & 2,2 \\
\hline & Incomplete RBBB & 5 & 7,3 & 9 & 10 \\
\hline & LPFB & - & - & 1 & 1,1 \\
\hline & LAFB & 17 & 25 & 24 & 26,8 \\
\hline & Extrasystoles & - & - & 3 & 3,3 \\
\hline & Early repolarization & 2 & 2,9 & 3 & 3,3 \\
\hline & Sinus tachycardia & 1 & 1,5 & 1 & 1,1 \\
\hline & Sinus arrhythmia & 1 & 1,5 & - & - \\
\hline & 31 & 45,6 & 27 & 30 \\
\hline \multicolumn{2}{|c|}{ Overall } & 68 & 100 & 90 & 100 \\
\hline \multicolumn{6}{|c|}{$\chi^{2}=10,414 ; p=0,034$} \\
\hline
\end{tabular}

In table 2 presented the prevalence of ECG abnormalities depending on value of WS. Both major and minor abnormalities were registered often in persons with abdominal obesity. Particularly in men with WS $>94 \mathrm{~cm}$ and women

with WS > $80 \mathrm{~cm}$ such abnormalities as LHV, $\mathrm{AF}$, minor ST-T abnormalities, incomplete RBBB, LPFB, LAFB, extrasystoles, early repolarization were more revealed than in residents without abdominal obesity.

\section{CONCLUSION:}

1. This population-based study revealed that only $36.7 \%$ of people had normal ECGs.

2. Changes in cardiac electrophysiology were not varies by BMI.

3. Both major and minor ECG abnormalities were more often in subjects with abdominal obesity.

\section{References:}

1. Kislyak OA, Malysheva NV, Chirkova NN (2004) Factory riska serdechno-sosudistyx zabolevaniy $\mathrm{v}$ razvitii bolezney svyazannyx $\mathrm{s}$ aterosklerozom. Klinicheskaya gerontologiya. 2004. pp.3

2. Bokeriya LA, Gudkova RG (2011) Serdechnososudistaya xirurgiya. 2011. pp.34

3. Mahmood SS, Levy D, et al. (2014) The Framingham Heart Study and the epidemiology of cardiovascular disease: a historical perspective. Lancet. 2014.

4. Oladapo OO, Salako L, et al. (2010) A prevalence of cardiometabolic risk factors among a rural Yoruba south-western Nigerian population: a population-based survey. Cardiovasc J Afr. 2010.

5. Njelekela MA, Liu E, et al. (2011) Socioeconomic status, urbanization, and cardiometabolic risk factors among middleaged adults in Tanzania. East Afr $\mathrm{J}$ Public Health. 2011.

6. Vangjeli C, Dicker P, et al. (2011) A polymorphism in ACE2 is associated with a lower risk for fatal cardiovascular events in females: the MORGAM project. J Renin Angiotensin Aldosterone Syst. 2011.

7. Amann U, Kirchberger I, et al. (2014) Longterm survival in patients with different combinations of evidence-based medications after incident acute myocardial infarction: results from the MONICA/KORA Myocardial Infarction Registry. Clin Res Cardiol. 2014.

8. Dagenais GR, Gerstein HC, et al. (2008) Effects of ramipril and rosiglitazone on cardiovascular and renal outcomes in people with impaired glucose tolerance or impaired fasting glucose: results of the Diabetes REduction Assessment with ramipril and rosiglitazone Medication (DREAM) trial. Diabetes Care. 2008.

9. Vassilaki M, Linardakis M, et al. (2015) The burden of behavioral risk factors for cardiovascular disease in Europe. A significant prevention deficit. Prev Med. 2015.

10. De Ruijter W (2008) The additional value of routine electrocardiograms in cardiovascular 


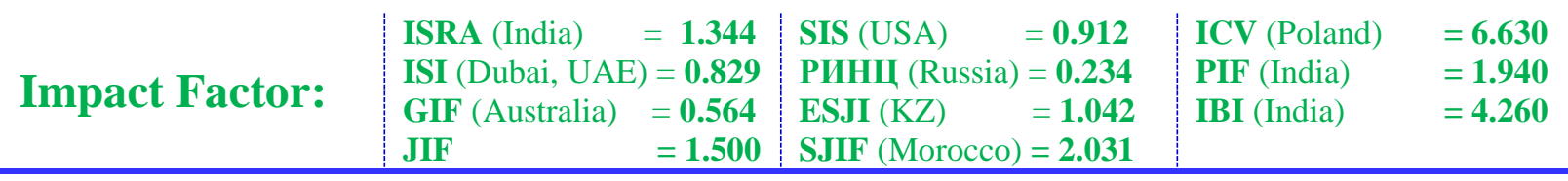

risk management of older people. Scand J Prim Health Care, 2008.

11. Yarnell JW, Patterson CC, et al. (2000) Comparison of weight in middle age, weight at 18 years, and weight change between, in predicting subsequent 14 year mortality and coronary events: Caerphilly Prospective Study. J Epidemiol Community Health. 2000.

12. Alpert MA, Terry BE, et al. (2000) The electrocardiogram in morbid obesity. Am J Cardiol. 2000.

13. Hillebrand S, de Mutsert R, et al. (2014) Body fat, especially visceral fat, is associated with electrocardiographic measures of sympathetic activation. Obesity (Silver Spring). 2014.

14. Fraley MA, Birchem JA, et al. (2005) Obesity and the electrocardiogram. Obes Rev. 2005.
15. Alpert MA, Nusair MB, et al. (2015) Effect of weight loss on ventricular repolarization in normotensive severely obese patients with and without heart failure. Am J Med Sci. 2015.

16. Falchi AG, Grecchi I, et al. (2014) Weight loss and $\mathrm{P}$ wave dispersion: a preliminary study. Obes Res Clin Pract. 2014.

17. Korean J (2010) Intern Med 2010. Variable Association between Components of the Metabolic Syndrome and Electrocardiographic Abnormalities in Korean Adults. Hong-Kyu Kim, Chul-Hee Kim et al.

18. Prineas R, Crow R, Zhang Zhu-Ming. (2010) The Minnesota Code Manual of Electrocardiographic Findings. Standards and Procedures for Measurement and Classification. Second edition, new and enlarged. New York, 2010. 